\title{
Klasifikasi Kadar Kolesterol Menggunakan Ekstraksi Ciri Moment Invariant dan Algoritma K-Nearest Neighbor (KNN)
}

\author{
Sekar Arum Nurhusni ${ }^{1 *}$, Riza Ibnu Adam ${ }^{2 *}$, Carudin ${ }^{3 *}$ \\ * Teknik Informatika, Universitas Singaperbangsa Karawang \\ sekar.arum17198@student.unsika.ac.id ${ }^{1}$, riza.adam@staff.unsika.ac.id ${ }^{2}, \underline{\text { carudin@staff.unsika.ac.id }}^{3}$
}

\begin{abstract}
Cholesterol is a fat that is mostly formed by the body itself, especially in the liver. Cholesterol is very useful for the body but will be very dangerous if it has excessive levels. The impact of excessive cholesterol is the emergence of deadly diseases such as heart disease, stroke and poor blood circulation. In this study, one of the medical sciences that can be used to detect cholesterol levels is Iridology. This iridology itself can be applied in computer science which is often referred to as Digital Image Processing. In this case, the feature recognition method will be used using Moment Invariant feature extraction and the K-Nearest Neighbor Algorithm. Where the data used is the Dataset from Ubiris V1. With the resulting accuracy of $84,8485 \%$.
\end{abstract}

\section{Pendahuluan}

Kolesterol adalah lemak yang sebagian besar di bentuk oleh tubuh sendiri terutama dalam hati. Kolesterol mempunyai beberapa fungsi untuk tubuh, diantaranya adalah untuk pembentuk hormon seperti hormon estrogen dan progesteron serta sebagai pembentuk asam empedu dan garam empedu. Walaupun kolesterol ini penting untuk pembentuk hormon dan garam empedu, namun jika kadarnya berlebihan di dalam tubuh dapat menimbulkan penyakitpenyakit kardiovaskuler dan penyakit metabolik lainnya [1].

Persentase penderita kolesterol tinggi menurut umur sebagian besar pada kelompok $>60$ tahun, dan penderita kolesterol terbanyak dimulai dari usia 15-34 tahun. Pada tahun 2015-2016, penyakit tidak menular yang disebabkan oleh kolesterol tinggi memiliki persentase terbesar yaitu 58,5\% pada tahun 2015 dan 52,3\% pada tahun 2016 [2]. Angka ini cukup tinggi dibandingkan dengan faktor penyakit yang lain. Untuk mencegah semakin tingginya persentase dari faktor ini maka perlu dilakukan sebuah tindakan dengan memprediksi kadar kolesterol secara dini dan berkala.

Diagnosis suatu penyakit biasanya dilakukan pada sebuah tes laboratorium, di mana tes tersebut sangat memerlukan banyak uang dan waktu. Dan seiring perkembangan zaman dalam dunia kesehatan terdapat salah satu metode yang dapat digunakan dalam upaya mendeteksi tingka tan kondisi pada tubuh dengan mengenali pola yang terbentuk pada iris mata atau yang lebih dikenal sebagai Iridologi. Iridologi (Inggris: Iridology) adalah ilmu yang mempelajari pola dan susunan serat pada iris mata.

Dengan memanfaatkan pengolahan citra digital maka proses diagnosis penyakit menggunakan metode iridologi dapat dilakukan. Proses pengolahan citra yang dilakukan pada penelitian ini yaitu menggunaka $\mathrm{n}$ ekstraksi ciri Moment Invariant yang diharapkan dapat melakukan analis is terhadap data dengan detail. Ekstraksi ciri ini pernah digunakan pada penelitian terdahulu dengan judul "Deteksi Iris Mata Untuk Menentukan Kelebihan Kolesterol Menggunakan Ekstraksi Ciri Moment Invariant dengan K-Means Clustering". Pada penelitian tersebut didapatkan hasil akurasi sistem yang dibuat yaitu 95\% [3].

Dalam melakukan proses pengolahan citra dalam mendeteksi kadar kolesterol dibutuhkan data citra iris mata manusia, yang dalam penelitian ini akan digunakan dataset iris mata manusia Ubiris v1. Dataset UBIRIS.v1 merupakan dataset yang terdiri dari 1877 citra yang dikumpulkan dari 241 orang dari September 2004 dengan melakukan dua sesi berbeda. Yang menjadi karakteristik atau membedakan dataset ini dengan dataset publik yang lain seperti CASIA dan UPOL adalah dataset ini menggabungkan gambar dengan beberapa faktor noise, sehingga memungkinkan untuk mendapatkan hasil evaluasi yang kuat.

Setelah berhasil dilakukan proses ekstraksi ciri maka data tesebut akan di klasifikasikan apakah termasuk kedalam 
kategori normal atau tinggi dengan menggunakan salah satu algoritma yang terdapat pada klasifikasi yaitu algoritma KNearest Neighbors (KNN) dengan melihat nilai ketetanggannya. Penelitian dengan algoritma ini pernah dilakukan sebelumnya dalam mengklasifikasi kadar kolesterol pada penelitian "Sistem Pendukung Keputusan Pengelompokan Status Kadar Kolesterol Menggunakan Algoritma K-Nearest Neighbor(KNN) Di Puskesmas Arjuno". Pada penelitian tersebut didapatkan hasil akurasi sebesar $88,5 \%$ dan error sebesar $11,5 \%$ dengan artian kinerja sistem sudah cukup baik [4]. Yang membedakan dengan penelitian sekarang yaitu penelitian ini dilakukan dengan menggunakan data data seperti ciri penyakit kolesterol seperti gejala dan sebagainya, sedangkan pada penelitian sekarang menggunakan citra sebagai media pendeteksian.

Penelitian pendahulu lain yang dapat dijadikan sebagai pendukung penelitian ini yaitu "Deteksi Kolesterol Menggunakan Citra Mata Berbasis Local Binary Pattern (LBP) dan Support Vector Machine (SVM) [5], juga dilakukan pada "Deteksi Kelebihan Kolesterol Melalui Citra Iris Mata dengan Metode Discrete Wavelet Transform dan Klasifikasi K-Nearest Neighbor" [6], dan juga "Seleksi Fitur Information Gain untuk Klasifikasi Penyakit Jantung Menggunakan Kombinasi Metode K-Nearest Neighbor dan Naive Bayes [7].

Pada penelitian ini, diterapkan metode ekstraksi ciri menggunakan moment invariant dan metode $\mathrm{KNN}$ untuk mendeteksi kadar kolesterol. Selain itu dilakukan pula evaluasi sistem setelah penggabungan metode ekstraksi ciri moment invariant dan metode KNN. Diharapkan penelitian ini dapat menjadi tambahan acuan pada pembangunan sistem untuk memprediksi penyakit menggunakan teknik pengolahan citra digital dengan metode ekstraksi moment invariant dan metode $\mathrm{KNN}$ dalam memprediksi tingkat kadar kolesterol.

\section{LANDASAN TEORI}

\section{A. Kecerdasan Buatan}

Artificial intelligence atau kecerdasan buatan merupakan bagian dari ilmu yang membuat mesin (komputer) bekerja seperti manusia [8]. Aplikasi kecerdasan buatan terdiri dari 2 bagian utama yang harus dimiliki yaitu:

1) Basis pengetahuan (Knowledge-Base), berisi fakta-fakta, teori, pemikiran.

2) Motor Inferensi (Inference Engine), kemampuan menarik kesimpulan berdasarkan pengalaman.

\section{B. Machine Learning}

Pembelajaran mesin atau machine learning merupakan metode analitik yang dapat membantu mengatasi masalah berupa big data dengan mengembangk an algoritme di komputer. Dengan menggunakan data, pembelajaran mesin memungkinkan komputer menemukan wawasan tersembunyi tanpa harus memprogramnya secara mendetail saat mencarinya. Pembelajaran mesin merupakan salah satu cabang dari mata pelajaran AI (kecerdasan buatan) yang menganalisis proses pembuatan sistem berdasarkan data yang diterima.

\section{Pengolahan Citra Digital}

Citra adalah persamaan, gambar atau tiruan dari suatu objek. Citra dapat berupa sinyal video (gambar di TV), foto, atau sinyal digital, dan dapat disimpa $\mathrm{n}$ langsung di media penyimpanan. Gambar yang dapat diolah atau diolah oleh komputer disebut citra digital. Setiap citra dapat diperoleh melalui akuisisi citra, yaitu proses yang dilakukan untuk memperoleh citra digital yang akan dicitrakan. Pencitraan adalah cara mengubah gambar yang terlihat (seperti foto, gambar, patung, dan lain-lain.

Dalam pengelolaan citra diperlukan proses pra-pemrosesan yang bertujuan untuk meningkatkan kualitas citra dengan mengatur kontras dan kecerahan, menghilangkan noise, mengembalikan citra, mentransformasi citra, dan menentukan bagian citra menjadi diamati, sehingga meningkatkan citra. Salah satu proses preprocessing adalah mengubah citra asli (color / RGB) menjadi citra grayscale (grayscale). Nilai intensitas setiap piksel pada citra grayscale merupakan nilai tunggal, dimana nilai intensitas berada dalam interval 0-255, sedangkan pada citra berwarna setiap piksel membutuhkan tiga nilai intensitas dengan interval 0-255. Semakin dekat nilainya ke 255, semakin cerah tingkat keabuannya. Pada dasarnya proses ini dilakukan dengan cara meratakan nilai piksel dari 3 nilai RGB menjadi 1 nilai [9].

\section{K-Nearest Neighbor}

$\mathrm{K}$ Nearest Neighbor (KNN) merupakan metode yang diawasi, artinya membutuhkan data latih untuk mengklasifikasikan objek terdekat. Prinsip kerja K- terdekat tetangga adalah mencari jarak terpendek antara data yang akan dievaluasi dan tetangga dalam data latih [10].

Selama proses pelatihan, dokumen akan dikelompokkan secara manual menurut kategori yang telah ditentukan. Setelah itu, dokumen akan memasuki tahap preprocessing yang akan menghasilkan bobot untuk setiap kata di semua dokumen pelatihan. Selanjutnya, hitung kemiripan antara vektor dokumen pengujian dan setiap dokumen pelatihan klasifikasi. Untuk mencari kesamaan dokumen digunakan metode cosine similarity. Metode ini dapat digunakan untuk menjelaskan jarak setiap dokumen berdasarkan kesamaan dokumen.

\section{E. Iridologi}

Iridology atau metode medis yang biasa disebut dengan diagnosis iris menyatakan bahwa setiap bagian tubuh dapat diwakili oleh area yang terdapat pada iris (bagian yang berwarna pada pupil) [11].

Iridologi adalah ilmu dan praktik yang dapat mengungkap adanya peradangan (inflamasi), penumpukan racun dalam jaringan, penyumbatan kelenjar (kongesti), lokasi organ (organ mana) dan tingkat keparahan penyakit (akut, subakut) , Kronis dan degeneratif) [12]. Dengan mengamati iris mata, melalui kondisi fisik seseorang, seseorang dapat melihat, misalnya, keadaannya sangat lemah atau sangat kuat, tingkat kesehatannya, dan transisi menuju keparahan atau proses 
pemulihan. Dilansir dari brilio.net berikut beberapa penyakit yang dapat di deteksi oleh iris mata menurut Brightside dapat telihat pada Tabel 1 .

TABEL I.

CitRa PENYAKIT IRIS MATA

\begin{tabular}{|l|l|l|}
\hline Nama Penyakit & Gambar & Keterangan \\
\hline $\begin{array}{l}\text { Infeksi kandung } \\
\text { kemih }\end{array}$ & $\begin{array}{l}\text { Muncul titik puth } \\
\text { pada kornea mata }\end{array}$ \\
\hline $\begin{array}{l}\text { Kolesterol tinggi } \\
\text { tekanan intraokular } \\
\text { (glauma), diabetes }\end{array}$ & $\begin{array}{l}\text { Adanya lingkaran } \\
\text { putih di sekeliling } \\
\text { iris mata }\end{array}$ \\
\hline $\begin{array}{l}\text { Kecapean dan } \\
\text { kurang tidur }\end{array}$ & $\begin{array}{l}\text { Mata merah tiba- } \\
\text { tiba }\end{array}$ \\
\hline $\begin{array}{l}\text { Hepatitis } \\
\text { Pinguecula }\end{array}$ & $\begin{array}{l}\text { Mata membengkak } \\
\text { kuning }\end{array}$ \\
\hline
\end{tabular}

\section{F. Moment Invariant}

Momen Invariant yaitu sekelompok momen yang mengidentifikasikan keunikan atau karakteristik global dari bentuk citra dan menyediakan informasi tipe-tipe geometri citra. Momen invariant telah diperkenalkan oleh $\mathrm{Hu}$ pada tahun 1961. Hu memperkenalkan momen invariant untuk citra digital dengan ukuran $\mathrm{M} \times \mathrm{N}$ piksel, dihitung dengan menggunakan rumus persaman:

$$
m_{p q}=\sum_{x=1}^{M} \sum_{\mathrm{y}=1}^{N} x^{p} y^{p} f(x, y)
$$

dengan $\mathrm{f}(\mathrm{x}, \mathrm{y})$ merupakan nilai piksel pada koordinat $(\mathrm{x}, \mathrm{y})$.

Invarian translasi dapat dihitung dengan menggunakan central moment yang didefinisikan dengan persamaan:

$$
\mu_{p q}=\sum_{x=1} \sum_{\mathrm{y}=1} \mathrm{M}(x-\bar{x})^{p}(y-\bar{y} q f(x, y)
$$

dengan $\bar{x}=\underline{m 10}$, dan $\bar{y}=\underline{m 01}$
Central moment yang dinormalisasi didefinisikan dengan persamaan:

$$
n p q=\frac{\mu p q}{(\mu 00)^{\lambda}}
$$

Dengan $\lambda=(i+j)+1$

2

Berdasarkan momen ternormalisasi di atas, $\mathrm{Hu}$ memperkenalkan tujuh invariant yang diberikan dalam persamaan:

$$
\begin{aligned}
& M_{1}=n_{20}+n_{02} \\
& M_{2}=\left(n_{20}-n_{02}\right)^{2}+4 n_{11} 2 \\
& M_{3}=\left(n_{30}-3 n_{12}\right)^{2}+\left(3 n_{21}-n_{03}\right)^{2} \\
& M_{4}=\left(n_{30}+n_{12}\right)^{2}+\left(n_{21}+n_{03}\right)^{2} \\
& M_{5}=\left(n_{30}-3 n_{12}\right)\left(n_{30}+n_{12}\right)\left[\left(n_{30}+n_{12}\right)^{2}-3\left(n_{21}+n_{03}\right.\right. \\
& )^{2}\right]+\left(3 n_{21}-n_{03}\right)\left(n_{21}+n_{03}\right)\left[3\left(n_{30}+n_{12}\right)^{2}-\left(n_{21}+n_{03}\right)^{2}\right] \\
& M_{6}=\left(n_{20}-n_{02}\right)\left[\left(n_{30}+n_{12}\right)^{2}-\left(n_{21}-n_{03}\right)^{2}\right]+4 n_{11}\left(n^{30}+\right. \\
& \left.n_{12}\right)\left(n_{21}+n_{03}\right) \\
& M_{7}=\left(3 n_{21}-n_{03}\right)\left(n_{30}+n_{12}\right)\left[\left(n_{30}+n_{12}\right)^{2}-3\left(n_{21}+n_{03}\right)^{2}\right] \\
& -\left(n_{30}+3 n_{12}\right)\left(n_{21}+n_{03}\right)\left[3\left(n_{30}-n_{12}\right)^{2}-\left(n_{21}+n_{03}\right)^{2}\right]
\end{aligned}
$$

Fitur moment invariant berguna untuk menjelaskan objek dengan menghitung area objek. Fitur ini menggunakan dasar moment pusat yang ternormalisasi. Moment yang dihasilkan dapat digunakan untuk menangani penyekalan, rotasi gambar, dan translasi

\section{G. Ubiris.v1}

Dataset UBIRIS.v1 merupakan dataset citra iris mata yang terdiri dari 1877 citra yang dikumpulkan dari 241 orang selama pada September 2004 dalam dua sesi yang berbeda. Karakteristik atau yang membedakan dataset ini dengan dataset publik dan gratis yang ada seperti CASIA dan UPOL adalah pada dataset ini ia menggabungkan gambar dengan beberapa faktor noisy, sehingga memungkink an mendapatkan hasil evaluasi metode pengenalan iris mata yang kuat.

Pada sesi pengambilan gambar pertama dilakukan percobaan untuk meminimalkan faktor noise, khususnya yang berhubungan dengan pantulan, luminositas dan kontras, dengan memasang kerangka pengambilan gambar didalam ruang gelap. Di sesi kedua, dilakukan pergantian tempat dalam pengambilan untuk memperkenalkan faktor luminositas alami. Ini mempengaruhi dalam masalah reflesksi, kontras, luminositas dan fokus. Gambar yang dikumpulkan pada tahap ini mensimulasikan gambar yang ditangkap oleh sistem penglihatan tanpa atau dengan partisipasi aktif minimal dari subjek, menambahkan beberapa masalah kebisingan atau noise data. 


\section{METODE}

\section{A. Objek Penelitian}

Objek penelitian ini adalah iris mata pada manusia dengan tingkat kolesterol tinggi baik remaja sampai orang tua, terutama untuk mereka yang memiliki gejala. Dengan mengaplikasikan salah satu kecerdasan buatan pada Machine Learning yaitu Klasifikasi. Agar tingkat kolesterol dapat terdeksi maka dilakukan pemrosesan gambar menggunakan salah satu algoritma klasifikasi yaitu KNN dimana pengklasifikasian dilakukan berdasarkan ketetanggaan terdekat. Dataset yang diambil yaitu merupakan dataset publik yaitu Ubiris V1. Yang mana data tersebut merupakan kumpulan data citra mata yang terdiri dari 1877 citra yang dikumpulkan dari 241 orang sejak September 2004 yang di kelompokan kedalam 2 bagian. Citra yang ada merupakan citra umum yang terdiri dari berbagai macam penyakit. Dataset ini digunakan di berbagai macam penelit ian untuk mendeteksi penyakit melalui iris mata. Citra ini di ambil dengan camera Nikon E5700 dengan representasi warna berupa RGB.

\section{B. Metode Penelitian}

Dalam pengembangan kecerdasan buatan ini dilakukan pengambilan data menggunakan data publik yaitu ubiris v1. Lalu dilakukan pre-processing pada citra mata dan data tersebut dilanjutkan dengan melakukan tahapan ekstraksi ciri terhadap data training untuk melakukan pelatihan pada algoritma yang dipakai pada penelitian ini yaitu algoritma KNN dan menggunakan data testing untuk mengetahui performa algoritma yang sudah dilatih sebelumnya ketika menemuk an data baru yang belum pernah dilihat sebelumnya.

\section{Rancangan Penelitian}

Tahapan pengerjaan penelitian Klasifikasi Kadar Kolesterol Menggunakan Ekstraksi Ciri Moment Invariant dan KNN tersaji dalam Gambar 1.

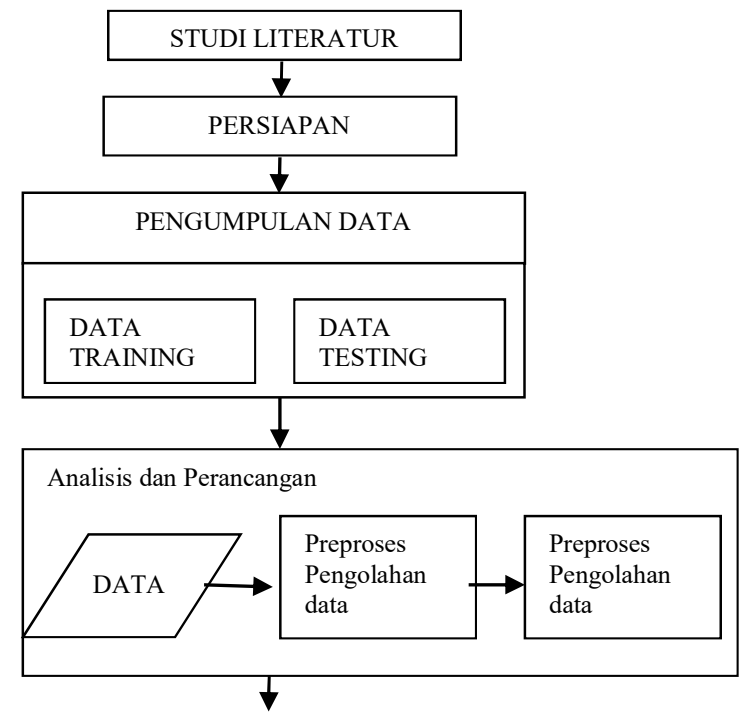

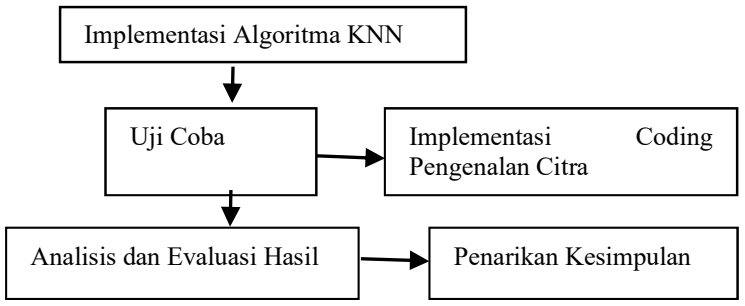

Gambar 1. Tahapan Rancangan Penelitian

Gambar 1 menjelaskan tahapan penelitian dimulai dari studi literature, persiapan, pengumpulan data, analisa perancangan, implementasi algoritma KNN, uji coba dan analisa serta penarikan kesimpulan.

\section{HASIL DAN PEMBAHASAN}

\section{A. Hasil Penelitian}

\section{Pengumpulan Data}

Data yang ada didapatkan dari ubiris v1. Dilakukan pemilihan data citra untuk dilakukan pemrosesan data. Di pilih 15 citra yang merupakan citra kolesterol dan 18 citra dengan tingkat kolesterol normal yang dimasukan kedalam data training dan 21 citra untuk data testing. Citra kolesterol dapat dilihat pada Tabel 2 .

TABEL II. Citra MATA Kolesterol

\begin{tabular}{|l|l|l|l|}
\hline Citra 1 & Citra 9 & \\
\hline Citra 2 & & Citra 10 & \\
\hline Citra 3 & & Citra 11 & \\
\hline Citra 4 & & Citra 12 & \\
\hline Citra 5 & & Citra 13 & \\
\hline Citra 6 & & & \\
\hline & & & \\
\hline
\end{tabular}


2. Analisis dan Perancangan

Data training dan data testing yang telah dikumpulkan akan dilakukan beberapa proses atau tahapan sebagai berikut :

a. Preproses Data

Sebelum data diproses, dilakukan beberapa tahapan preprosesing data atau persiapan data sebelum dilakukan proses ekstraksi ciri Moment Invarian dan juga Klasifikasi menggunakan KNN. Tahapan tersebut meliputi :

1) Merubah ukuran citra

Citra yang sudah di pilih harus melewati proses preposesing dengan menyamakan ukuran citra menjadi ukuran 150x200. Agar proses pendeteksian dapat dilakukan dengan mudah dan akurat.

2) Konversi RGB menjadi Grayscale

Setelah ukuran citra sama semua maka dilakukan proses grayscale untuk merubah citra yang semula merupakan citra rgb menjadi citra keabu-abuan.

3) Segmentasi Daughman

Setelah melewati proses tersebut maka dilakukan tahapan segmentasi terhadap semua citra iris mata dengan menggunakan Daugman's integrodifferential operator. Proses Daughman's ini untuk mencari lokasi dimana iris mata berada dengan cara mendeteksi iris mata yang berupa lingkaran.

4) Menghilangkan Background Citra

Setelah iris mata di deteksi dengan menerapkan proses Segmentasi Daughman ini maka background iris mata tersebut atau sekitaran mata seperti kelopak mata dan lain lain dihilangkan atau nilainya di ubah menjadi 0 sehingga yang di proses hanya iris mata saja agar proses dapat lebih di fokuskan.

5) Thresholding

Pada tahapan ini dilakukan proses pemisahan citra dengan background. Proses ini nantinya akan menghasilkan keluaran berupa citra biner yang bernilai 1 dan 0 .

\section{b. Moment Invariant}

1) Kolesterol

Nilai invariant pada citra kolesterol tersaji dalam Tabel 3.

TABEL III

Nilai INVARIANT CitRa Kolesterol

\begin{tabular}{|l|c|c|c|c|c|c|c|}
\hline Nama & M1 & M2 & M3 & M4 & M5 & M6 & M7 \\
\hline Citra 1 & 0.2141 & 7.4402 & 5.6754 & 1.839 & -4.0079 & - & - \\
& & & & & & 3.7709 & 1.0529 \\
\hline Citra 2 & 0.2519 & 0.0014 & 0.0002 & 0.0013 & 3.6805 & - & 2.8968 \\
& 1 & 788 & 1971 & 966 & & 5.2714 & \\
\hline Citra 3 & 0.1592 & 1.2899 & 5.1384 & 1.1534 & 3.4341 & - & -4.177 \\
& 3 & & & & & 1.2473 & \\
\hline Citra 4 & 0.1935 & 0.0003 & 3.3972 & 0.0001 & -2.5067 & - & - \\
& & 1834 & & 1025 & & 3.270 & 3.270 \\
& & & & & & 4 & 4 \\
\hline Citra 5 & 0.1653 & 0.0001 & 3.6109 & 7.1342 & -8.7347 & - & 6.5517 \\
\hline
\end{tabular}

\begin{tabular}{|l|c|c|c|c|c|c|c|}
\hline Citra 6 & 0.1668 & 2.7812 & 1.6934 & 9.5814 & 3.0521 & - & - \\
& 1 & & & & & $\begin{array}{c}7.004 \\
9\end{array}$ & $\begin{array}{c}5.293 \\
1\end{array}$ \\
\hline Citra & 0.2043 & 8.1867 & 2.6671 & 9.3279 & 2.9781 & - & - \\
7 & 5 & & & & & 1.6374 & 1.5263 \\
\hline Citra8 & $\begin{array}{c}0.2767 \\
5\end{array}$ & 7.9712 & 5.3679 & $\begin{array}{c}8.9330 \\
5\end{array}$ & 3.0116 & - & 9.3883 \\
& & & & 9.674 & \\
\hline Citra 9 & 0.1897 & 0.0002 & 1.4609 & 8.6278 & -2.4178 & - & - \\
& 4 & 5119 & 1 & 1 & & 1.2491 & 1.6736 \\
\hline Citra & 0.1809 & 0.0004 & 0.0001 & 1.1698 & 2.3921 & - & - \\
10 & 1 & 6786 & 1635 & 05 & 1 & 2.259 & 2.509 \\
& & & & & & 6 & 4 \\
\hline Citra & 0.1529 & 3.9040 & 1.1443 & 4.2814 & -3.4159 & - & 1.1738 \\
11 & 6 & 06 & 09 & & 8.4557 & \\
\hline Citra & 0.2706 & 9.4579 & 9.8775 & 3.5630 & 1.0145 & - & 3.5372 \\
12 & 3 & 06 & 07 & 5 & & 1.091 & \\
& & & & & & 3 & \\
\hline Citra 13 & 0.2462 & 9.3023 & 1.7981 & 3.4745 & 8.4436 & - & 1.7831 \\
& 2 & 05 & 05 & 05 & 1 & 6.5321 & \\
\hline Citra 14 & 0.1699 & 0.0003 & 7.2079 & 1.7542 & 2.0051 & -2.8754 & - \\
& 1 & 3409 & 05 & 05 & 0 & & 4.9262 \\
\hline Citra 15 & 0.2082 & 2.6633 & 3.7115 & 8.8057 & -7.2922 & -3.2919 & - \\
& 4 & 05 & 06 & 05 & & & 1.4727 \\
\hline
\end{tabular}

Tabel tersebut merupakan hasil dari 7 nilai ciri dari pengenalan citra menggunakan moment invariant pada citra kolesterol yang digunakan dalam penelitian ini.

2). Normal

Nilai Invariant dari citra normal dapat dilihat Tabel 4.

TABEL IV.

NILAI INVARIANT CITRA NORMAL

\begin{tabular}{|c|c|c|c|c|c|c|c|}
\hline Nama & M1 & M2 & M3 & M4 & M5 & M6 & M7 \\
\hline Citra 1 & 0.6675 & 9.8047 & 4.1364 & 2.0516 & $\begin{array}{c}- \\
3.7679\end{array}$ & 1.417 & -9.7832 \\
\hline Citra 2 & 0.16331 & 4.7408 & 2.2127 & 1.3308 & 3.1715 & -5.8815 & -2.0083 \\
\hline Citra 3 & 0.16331 & 8.8783 & 2.2709 & 5.1398 & 8.3689 & -1.0009 & -1.0114 \\
\hline Citra 4 & 0.16135 & 2.6612 & 5.0125 & 3.7080 & $9 . \overline{8143}$ & -5.8647 & -4.0047 \\
\hline Citra 5 & 0.17069 & 4.2410 & 9.4931 & 9.0643 & 6.3712 & -5.1712 & -1.2189 \\
\hline Citra 6 & 0.16826 & 6.5452 & 1.3460 & 2.8816 & $6 . \overline{1740}$ & -2.2134 & 1.8686 \\
\hline Citra 7 & 0.16407 & 7.0513 & 6.1555 & 1.4536 & $\begin{array}{c}- \\
2.1735\end{array}$ & 6.5753 & 3.0445 \\
\hline Citra 8 & 0.16005 & 3.9042 & 3.8534 & 8.4154 & $\begin{array}{c}- \\
4.8761\end{array}$ & -5.2309 & -4.5803 \\
\hline Citra 9 & 0.16298 & 1.6115 & 2.9188 & 1.1908 & 8.3464 & -1.4971 & -1.6811 \\
\hline Citra10 & 0.16397 & 4.1681 & 7.7469 & 6.3485 & 1.3655 & -6.8931 & -3.4548 \\
\hline Citra 11 & 0.19903 & 6.0571 & 1.9018 & 2.4125 & 3.4311 & -1.2424 & 4.8738 \\
\hline Citra 12 & 0.17798 & 1.9168 & 1.3356 & 3.3919 & 1.6968 & -8.3374 & 4.2553 \\
\hline Citra 13 & 0.16264 & 7.0541 & 7.7887 & 7.0585 & 4.1488 & -1.7862 & -3.5165 \\
\hline \begin{tabular}{|l|} 
Citra14 \\
\end{tabular} & 0.17119 & 4.9132 & 1.0855 & 7.0043 & 2.7262 & -3.8018 & 1.1734 \\
\hline Citra 15 & 0.17054 & 1.7430 & 6.2358 & 5.5327 & $4 . \overline{4} 748$ & 6.3242 & 2.6919 \\
\hline Citra 16 & 0.1784 & 1.4824 & 1.2413 & 1.2124 & 9.8028 & 4.9165 & -1.8618 \\
\hline Citra 17 & 0.17681 & 2.2991 & 3.0701 & 6.8556 & 1.6372 & -9.1978 & 1.2391 \\
\hline
\end{tabular}

Tabel tersebut merupakan 7 nilai invariant pada citra normal yang dihasilkan dari proses ekstraksi ciri menggunakan moment invariant yang dilakukan.

3. Hasil Klasifikasi Algoritma KNN Setelah semua data uji telah dilakukan preprosesing data dan juga telah dikenalkan dengan metode pengenalan ciri Moment Invariant. Maka selanjutnya di terapkan metode klasifikasi yang pada penelitian ini yaitu menggunakan Algorit ma K-Nearest Neighbor. 
Target latih sebelum melewati proses klasifikasi dapat di lihat pada Tabel 5 .

TABEL V.

DATA LATIH

\begin{tabular}{|l|l|}
\hline No & Status \\
\hline 1 & Kolesterol \\
\hline 2 & Kolesterol \\
\hline 3 & Kolesterol \\
\hline 4 & Kolesterol \\
\hline 5 & Kolesterol \\
\hline 6 & Kolesterol \\
\hline 7 & Kolesterol \\
\hline 8 & Kolesterol \\
\hline 9 & Kolesterol \\
\hline 10 & Kolesterol \\
\hline 11 & Kolesterol \\
\hline 12 & Kolesterol \\
\hline 13 & Kolesterol \\
\hline 14 & Kolesterol \\
\hline 15 & Kolesterol \\
\hline 16 & Normal \\
\hline 17 & Normal \\
\hline 18 & Normal \\
\hline 19 & Normal \\
\hline 20 & Normal \\
\hline 21 & Normal \\
\hline 22 & Normal \\
\hline 23 & Normal \\
\hline 24 & Normal \\
\hline 25 & Normal \\
\hline 26 & Normal \\
\hline 27 & Normal \\
\hline 28 & Normal \\
\hline 29 & Normal \\
\hline 30 & Normal \\
\hline 31 & Normal \\
\hline 32 & Normal \\
\hline 33 & Normal \\
\hline & \\
\hline
\end{tabular}

Setelah target latih di dapatkan maka data akan di klasifikasikan dan setelah dilakukan proses klasifikasi hasil data dapat di lihat pada Tabel 6 .

TABEL VI.

Hasil Data Latih

\begin{tabular}{|l|l|l|l|}
\hline No & Status awal & Status Latih & \multicolumn{1}{|c|}{ Hasil } \\
\hline 1 & Kolesterol & Kolesterol & Sesuai \\
\hline 2 & Kolesterol & Kolesterol & Sesuai \\
\hline 3 & Kolesterol & Kolesterol & Sesuai \\
\hline 4 & Kolesterol & Kolesterol & Sesuai \\
\hline 5 & Kolesterol & Kolesterol & Sesuai \\
\hline 6 & Kolesterol & Kolesterol & Sesuai \\
\hline 7 & Kolesterol & Kolesterol & Sesuai \\
\hline 8 & Kolesterol & Kolesterol & Sesuai \\
\hline 9 & Kolesterol & Kolesterol & Sesuai \\
\hline 10 & Kolesterol & Kolesterol & Sesuai \\
\hline 11 & Kolesterol & Kolesterol & Sesuai \\
\hline 12 & Kolesterol & Kolesterol & Sesuai \\
\hline 13 & Kolesterol & Kolesterol & Sesuai \\
\hline 14 & Kolesterol & Kolesterol & Sesuai \\
\hline 15 & Kolesterol & Kolesterol & Sesuai \\
\hline 16 & Normal & Kolesterol & Tidak Sesuai \\
\hline 17 & Normal & Normal & Sesuai \\
\hline 18 & Normal & Kolesterol & Tidak Sesuai \\
\hline
\end{tabular}

\begin{tabular}{|l|l|l|l|}
\hline 19 & Normal & Normal & Sesuai \\
\hline 20 & Normal & Normal & Sesuai \\
\hline 21 & Normal & Normal & Sesuai \\
\hline 22 & Normal & Normal & Sesuai \\
\hline 23 & Normal & Normal & Sesuai \\
\hline 24 & Normal & Normal & Sesuai \\
\hline 25 & Normal & Kolesterol & Tidak Sesuai \\
\hline 26 & Normal & Normal & Sesuai \\
\hline 27 & Normal & Normal & Sesuai \\
\hline 28 & Normal & Normal & Sesuai \\
\hline 29 & Normal & Normal & Sesuai \\
\hline 30 & Normal & Kolesterol & Tidak Sesuai \\
\hline 31 & Normal & Normal & Sesuai \\
\hline 32 & Normal & Kolesterol & Tidak Sesuai \\
\hline 33 & Normal & Normal & Sesuai \\
\hline
\end{tabular}

Setelah dilakukan proses klasifikasi menggunakan algoritma K-Nearest Neighbor maka didpatkan data citra kolesterol sebanyak 20 citra, dan citra normal sebanyak 13 citra. Dari data tersebut artinya terdapat 28 citra sesuai dan 5 citra tidak sesuai dengan begitu akurasi yang didapatkan yaitu $84,8485 \%$.

\section{Uji Coba}

Pada tahapan ini semua proses yang dilakukan akan di implementasikan kedalam bahasa pemrograman Matlab menggunakan software Matlab R2017b. Tampilan gui dapat di lihat pada Gambar 2. Berikut.

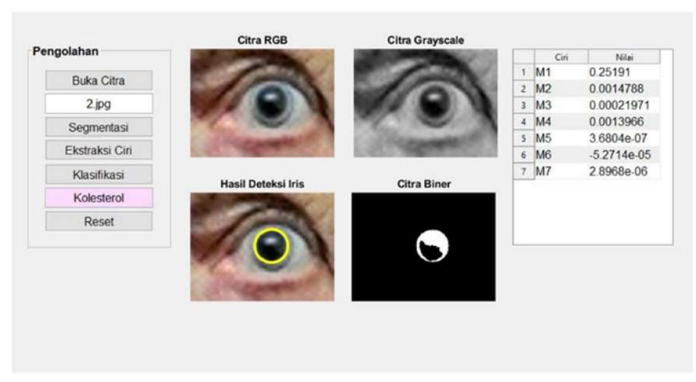

Gambar 2. GUI aplikasi deteksi kolesterol

Pada proses pengkodean yang di implementasikan dengan tampilan gui sebagai berikut. Dimana gui tersebut berisikan tombol buka citra untuk mengambil citra yang ingin di uji lalu terdapat fitur segmentasi dimana citra yang di pilih akan di lakukan segmentasi menjadi citra greyscale lalu dilakukan pendeteksian iris dan terakhir menjadi citra yang bernilai biner. Lalu ada fitur ekstraksi citra yang akan menampilkan 7 nilai invariant dari citra tersebut. Dan setelah itu ada fitur klasifikasi yang akan menampilkan hasil apakah citra tersebut termasuk kedalam citra kolesterol atau normal. Dan terakhir ada fitur riset untuk mengosongkan semua kolom dan memulai ulang proses tersebut.

\section{B. Pembahasan}

Berikut nilai invariant pada citra kolesterol dan normal dalam bentuk grafik. 


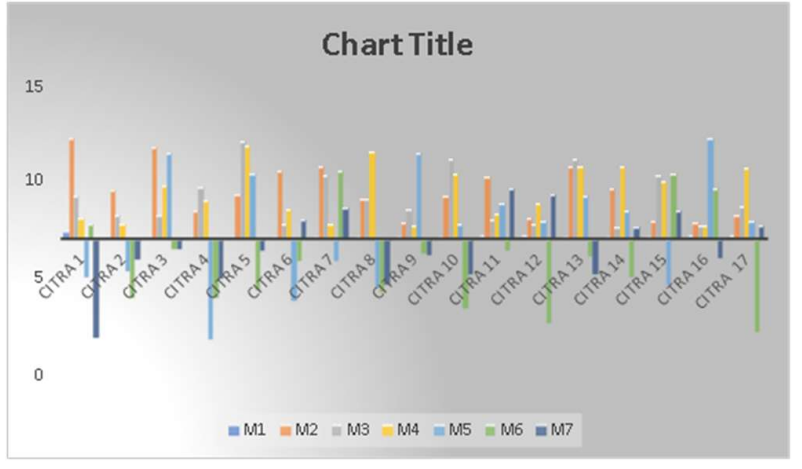

Gambar 3. Grafik Nilai Invariant Citra Normal

Dalam grafik tersebut hal yang paling terlihat pada citra kolesterol memiliki nilai invariant yang bervariasi dan pada M1 dan M2 memiliki nilai yang relatif kecil sedangkan pada citra normal dapat dilihat bahwa setiap citra memiliki grafik yang hampir seragam tidak ada perbedaan yang terlalu mencolok.Setelah semua citra dilakukan pengenalan ciri maka selanjutnya dilakukan proses klasifikasi menggunakan algoritma KNN untuk mendapatkan citra mana saja yang dikategorikan sebagai citra kolesterol dan yang mana citra normal.

Setelah dilakukan semua proses tersebut maka selanjutnya dilakukan proses uji coba dengan membuat sebuah program dengan bahasa yang dikenali oleh komputer dan menghasilkan output yang dikenal oleh manusia. Maka di buat gui untuk merepresentasikan hasil dari proses yang sudah dilalui tersebut. Setelah itu dilakukan evaluasi terhadap proses yang dilakukan. Yang mana dari ekstraksi ciri moment invariant dan juga algoritma KNN ini mendapatkan hasil akurasi $84.8485 \%$.

\section{KESIMPULAN}

Pada penelitian ini menerapkan teknologi pengolahan citra digital terhadap salah satu metode deteksi penyakit yang sering disebut dengan iridologi atau mendeteksi penyakit dengan melihat pola pada iris mata manusia. Dataset citra yang digunakan pada penelitian ini yaitu dataset ubiris v1 yang mana untuk menerapkan pada penelitian ini akan digunakan 15 citra yang dikategorikan sebagai citra kolesterol dan 18 citra yang merupakan citra dengan kolesterol normal. Dari semua citra yang dipilih akan dilakukan beberapa tahap preproses untuk memudahkan pengenalan citra. Selanjutnya dilakukan pengenalan citra menggunakan ekstraksi ciri moment invariant untuk mendapatkan nilai invariant yang dianggap sebagai ciri dari citra tersebut dan nantinya nilai tersebut yang merupakan ciri dari setiap citra yang ada akan diklasifikasikan sehingga dapat diketahui mana yang merupakan citra kolesterol dan yang normal.

Hasil dari dilakukannya ekstraksi ciri menggunakan moment invariant dan dilanjutkan dengan melakukan klasifikasi terhadap nilai invariant yang didapatkan yaitu dari 15 citra kolesterol dan 18 citra normal yang didapatkan, sistem membaca bahwa terdapat 20 citra kolesterol dan 13 citra normal. Dalam artian proses ekstraksi ciri menggunakan moment invariant dalam peneletian ini menghasilkan akurasi sebesar $84.8485 \%$ angka tersebut menunjukan akurasi yang cukup baik.

Dari hasil penelitian yang dilakukan, maka saran untuk penelitian selanjutnya dalam metode klasifikasi, kadar kolesterol dapat menggunakan dataset citra lain dengan jumlah yang lebih banyak. Selain itu menggunakan metode pengenalan citra yang lain yang memungkinkan untuk di aplikasikan kedalam metode atau algoritma k-nearest neighbor.

\section{DAFTAR PUSTAKA}

[1] Murray, Robert K. 2009. Biokimia Harper. Jakarta : EGC.

[2] Lyli, S. Sulistyawati. (2017). Penyakit Tidak Menular. Profil Penyakit Tidak Menular 2016. Jakarta : Kementerian Kesehatan RI.

[3] Rani, H. A. D., Supriyati, E., \& Khotimah, T. (2014). Deteksi Iris Mata untuk Menentukan Kelebihan Kolesterol menggunakan Ekstraksi Ciri Moment Invariant dengan K-Means Clustering. Prosiding SNATIF, 287-292.

[4] Kurniawan, C. T. (2017). SISTEM PENDUKUNG KEPUTUSAN PENGELOMPOKAN STATUS KADAR KOLESTEROL MENGGUNAKAN ALGORITMA K-NEAREST NEIGHBOR (KNN) DI PUSKESMAS ARJUNO. JATI (Jurnal Mahasiswa Teknik Informatika), 1(1), 135-143

[5] Waluya, D. P., Suhartono, E., \& Safitri, I. Deteksi Kolestero Menggunakan Citra Mata Berbasis Local Binary Pattern (LBP) Dan Support Vector Machine (SVM) Detection Of Cholesterol Using Eye Picture Based Local Binary Pattern (LBP) And Support Vector Machine (SVM)

[6] Enjelica, R. (2019). Deteksi Kelebihan Kolesterol melalui Citra Iris Mata dengan Metoda Discrete Wavelet Transform dan Klasifikasi KNearest Neighbor. Universitas Telkom, Bandung.

[7] Sari, Y. A., \& Arwan, A. (2018). Seleksi Fitur Information Gain untuk Klasifikas i Penyakit Jantung Menggunakan Kombinasi Metode KNearest Neighbor dan Naïve Bayes Human Detection and Tracking View project Smart Nutritio $\mathrm{n}$ Box View project. Jurnal Pengembangan Teknologi Informasi dan Ilmu Komputer e-ISSN, $2548,964 X$.

[8] Kusumadewi, S. (2003). Artificial Intelligence (Teknik dan Aplikasinya). Yogyakarta: Graha Ilmu.

[9] Andono, Pulung Nurtantio, Konsep Pengolahan Citra Digital, Ed. 1. Yogyakarta: Andi, (2015).

[10] Whidhiasih, Retno Nugroho et al. 2013. Klasifikasi Buah Belimbing Berdasarkan Citra Red-Green-Blue Menggunakan KNN dan LDA. Jurnal Penelitian Ilmu Komputer Universitas Pakuan Bogor : 29-35.

[11] Fahma ST MSc, 2007, Perancangan Algoritma Pengolahan Citra Mata Menjadi Citra Polar Iris Sebagai Bentuk Antara Sistem Biometrik, Universitas Sumatra Utara, Medan.

[12] Farida Sachran, 2005, Iridology: A Complete Guide To Diagnosing Through the Iris And To Related Forms of Treatment, New York, USA. 